\title{
A Review on Livestock Marketing in Ethiopia: Opportunities and Challenges
}

\author{
Amanuel Ayele \\ College of Agricultural Sciences, Wachemo University, P.O.Box 667, Hossana, Ethiopia
}

\begin{abstract}
Improving livestock marketing is critical to enhance households' livelihoods and alleviate poverty in the country. This paper reviewed relevant documents in Ethiopian livestock marketing to know livestock marketing system; livestock marketing channels and key actors; and opportunities and challenges of livestock marketing. The domestic livestock marketing structure in Ethiopia follows four tiers: namely bush, primary, secondary and tertiary/terminal markets. Many actors are involved in livestock and livestock products marketing, they are broadly classified as: livestock producers, traders, processors, retailers, food service providers, and consumers. Ethiopia exports livestock and livestock products to various Middle East and North African countries. The opportunities for livestock marketing in the country are resource availability; demand availability both regionally and in the Middle East; proximity to the markets of neighboring countries; development of export-abattoirs within the country and their substantial demand for lowland animals, especially shoats; and the tendency of both the government agencies and the NGOs to work towards integrating the pastoral marketing cooperatives with the export abattoirs supply chains. Despite the above-mentioned opportunities, livestock producers and other people who engaged in livestock marketing face various challenges in marketing their livestock and livestock products. The major challenges are: poorly developed market infrastructures; inadequate and inappropriate road transport facilities; poorly developed port facilities; few and unevenly distributed export abattoirs; absence of market information and promotional activities; prevalence of diseases; repeated import bans by the major importing countries; lack of formal trade among the neighboring countries; and natural disasters (drought, famine, wars).
\end{abstract}

Keywords: Livestock, marketing, challenges, opportunities, Ethiopia

DOI: $10.7176 / \mathrm{JMCR} / 59-01$

Publication date: August $31^{\text {st }} 2019$

\section{INTRODUCTION}

Ethiopia has the largest livestock population in Africa (CSA, 2012). Livestock sector has been contributing considerable portion to the country's economic development in general and agricultural and rural development in particular. It contributes $40 \%$ of the agricultural GDP, $18 \%$ of total GDP and $19 \%$ of foreign exchange earnings (CSA, 2012). Agricultural GDP represents the value of unprocessed or lightly processed agricultural produce at point of first sale. The contribution of livestock to cash income of smallholders accounts for $87 \%$ (Ahmed et al., 2003; CSA, 2007). About $80 \%$ of Ethiopian farmers use animal traction to plough their fields (IGAD, 2010).

The contributions of livestock can be well expressed at household level by its role in enhancing income, food security and social status (Bailey et al., 1999). The livestock sector supports the livelihoods of a large proportion of rural households in the country and may have an important role to play in rural poverty reduction strategies. By considering the size of the human population that depends on livestock production in Ethiopia, the development of domestic and export markets is critical to alleviating poverty, raising revenues and continuing the trend towards more market orientation (Aklilu, 2008). As Asfaw et al. (2011) indicates government policies have been supporting the development of this sector through forming exporter's associations, identifying potential export markets and facilitating export procedures.

The livestock marketing system is made up of pastoralists who raise animals, traders who buy animals in and around periodic markets throughout the rangelands, hoping to sell them at a profit elsewhere, transporters, local butchers, terminal market abattoirs, meat wholesalers, and, ultimately, consumers (Bailey et al., 1999). Marketing of livestock involve exchange of products like live animals, meat, milk, hides/skin and wool for cash or goods in kind (ILCA, 1990). The main objective of this paper was to review different literatures on opportunities and challenges of livestock marketing in the past and current livestock marketing system in Ethiopia. It also aimed to identify livestock marketing channels and key market actors for livestock product value chains.

\section{Overview of Livestock in Ethiopia National livestock population}

Ethiopia has the largest livestock population in Africa with livestock ownership currently supporting and sustaining the livelihoods of an estimated 83 percent of the rural poor (FAO, 2004; Asfaw et al., 2011; CSA, 2012). In 2012, Ethiopian sedentary private holdings were estimated at about 52.13 million heads of cattle, 24.2 million heads of sheep, 22.6 million heads of goats, 1.96 million horse, 6.4 million donkey, 0.37 million mules 
and 0.99 million camel (CSA, 2012). These livestock population estimates exclude the livestock population for pastoral areas, as there are no official statistics for those areas. Some rough expert estimates indicate that pastoral areas account for about $20 \%$ of cattle, $40 \%$ of sheep, and $40 \%$ of goats in the country (Hurissa, 2007). Ethiopia is home to many equines. According to IGAD (2011), Ethiopia contains over $40 \%$ of Sub-Saharan Africa's horses and donkeys and over $90 \%$ of the subcontinent's mules. World-wide, only China has more donkeys than Ethiopia. Ethiopian equines are working animals. Pack and riding animals compete successfully with wheeled vehicles because of the country's rugged terrain and poor road network, both in remote rural areas and in parts of some cities.

\section{Livestock production systems}

In Ethiopia, livestock is produced under two major production systems: the sedentary crop-livestock production system and the nomadic pastoral or agro-pastoral production system. The other growing livestock production systems are small-scale peri-urban and urban production systems and medium-to large-scale commercial livestock production systems (Asfaw et al., 2011).

The crop-livestock production system is based on limited community and/or private grazing areas and the use of crop residue and stubble. Diversification allows producers to mitigate the risk of crop failure or losses of livestock, while livestock is also an important input to crop production and vice versa. The pastoral production system is based on extensive community grazing land while agro-pastoralists are characterized by a combination of both pastoral and mixed crop-livestock production. Mixed-farm households practice both crop and livestock production. Both the mixed crop-livestock and the pastoral production systems are characterized as small-scale, low-input, and less commercially oriented, with very little or no vertical coordination. The common feature of these production systems is that livestock producers keep different livestock species for multiple uses. Private sector entries and capital investment into meat, dairy, and poultry farms have increased substantially over the last several years (Asfaw et al., 2011).

Women are usually responsible for feeding animals, cleaning barns, milking, processing milk and marketing of livestock products. Young children, especially girls between the ages of 7 and 15, are mostly responsible for managing calves, chicken and small ruminants and older boys are responsible for treating sick animals, constructing shelter, cutting grass and herding of cattle and small ruminants (Stroebel, 2004).

\section{Economic importance of livestock}

Almost all rural households are involved in some way with livestock production. The livestock sector plays a significant role in the Ethiopian economy at both the national and household levels. At the household level, livestock plays a critical economic and social role in the lives of pastoralists, agro-pastoralists, and smallholder farm households. Livestock serve as an important function in accumulating wealth, coping with shocks, and used as a store of value in the absence of financial institutions for saving (Asfaw et al., 2011). Livestock are a form of productive capital, providing a stream of desired goods and services, including milk, blood, manure, transport, and traction (Bailey et al., 1999). The role of livestock on the livelihoods of smallholder farmers include income generation, food security, use of manure in nutrient cycling, draft animal power and social functions (Stroebel, 2004). In addition to these, livestock serve as an asset and may provide a reserve that can be converted to cash in times of need. Livestock raising and selling enables the poor rural families (in particular women) to enter the cash economy. Livestock production provides increased stability in income for the family without disrupting other food producing activities (Berhanu, 2003).

In the case of smallholder mixed farming systems, livestock provides nutritious food, additional emergency and cash income, a means of transportation, farm outputs and inputs, draught power and fuels for cooking (Stroebel, 2004; Asfaw et al., 2011). In the highlands, manure of livestock used to maintain soil fertility and oxen provided draft power in crop production. In the highlands of Ethiopia, smallholders rear cattle, primarily for the supply of oxen power for crop production. Milk production, cash source, manure and fuel are considered as secondary. Cattle and equine play a vital role in smallholder farms for crop cultivation and transportation (Stroebel, 2004).

In the case of pastoralists, livestock solely represents a means to support their livelihoods. In the semi-arid low lands, cattle are the most important species because they supply milk for the subsistence of the pastoral families. In the more arid areas, however, goats and camels are the dominant species reared. Goats provide milk, meat and cash income, while camels provide milk, transport and, to a limited extent, meat to the nomadic pastoral population (Stroebel, 2004). In pastoral areas livestock are considered as a means of wealth accumulation and as indicators of status in the societal hierarchy (Belachew, 2004).

At national level the contribution of livestock and livestock products to the Ethiopian economy is significant, accounting for $40 \%$ of the agricultural gross domestic product, excluding the value of draught power, fuel, manure and transportation. Livestock and livestock products are also important and significant sources of foreign exchange earnings (Stroebel, 2004). Therefore, improving livestock production and marketing is critical 
to enhance livelihoods and to alleviate poverty in Ethiopia (Asfaw et al., 2011).

\section{Livestock Marketing in Ethiopia}

Market is a point or place or sphere within which price-making forces operate and exchanges of title tend to be accompanied by the actual movement of the goods and services affected (Andergachew, 1990). It is the set of the actual and potential buyers of a product (Kotler and Armstong, 2003). Markets link producers to consumers. Markets affect livestock producers either when they trade cattle or purchase food and other necessities. The pastoral households purchased cattle for different purposes including breeding, fattening, for gifts (marriage, circumcision, fines) or to be slaughtered and consumed (Misginaw, 2011).

Marketing system may be defined as the totality of product channels, market participants and business activities involved in the transfer of goods and services from producers to consumers. Marketing system is a collection of channels, intermediaries, and activities, which facilitate the physical distribution and economic exchange of goods (Kohls and Uhl, 1985).

Marketing can be described as the performance of all business activities that involved in the flow of products and services from the point of initial agricultural production until they are in the hands of consumers (Kohls and Uhl, 1985). According to (Malcolm et al., 2005) the term marketing is refer to activities, such as distribution, further transformation and promotion, that occur following the production of output. In agricultural economics, marketing is identified with various functions that add utility, or value for customers, to farm outputfor example, time, form, and place utility. Livestock marketing involves the sale, purchase or exchange of products such as livestock and livestock products like milk, meat, skins and hides for cash or goods in kind (ILCA, 1990).

\section{Livestock market participation and marketing actors}

Market access is a critical factor influencing market participation and risk management by pastoralists. According to McPeak (2000), pastoralists with better market access sell livestock at a higher rate. Marketing played a greater role in modifying herd sizes in high market access sites than in low market access sites during the drought. Barrett et al. (2004) indicated that pastoral households in Ethiopia participate in livestock markets, but in relatively small volumes and at varying rates over time. In pastoral areas livestock are sold to meet family cash needs to purchase food and clothes and pay for educational and medical expenses (Hurissa and Eshetu 2003; Gebremedhin et al., 2007).

In general, many actors are involved in livestock product marketing, broadly classified as: livestock producers, traders, processors, retailers, food service providers, and consumers. Private and public livestock inputs and service providers are other important market actors. The market actors may be involved in cattle only, sheep and goats only, or cattle, sheep, and goat transactions (Asfaw et al., 2011).

\section{Livestock market channels}

There are several marketing channels through which cattle, sheep, and goats flow to final consumers in both the domestic and export markets. In general, the cattle, sheep, and goat marketing channels are lengthy, without significant value-added activities (Asfaw et al., 2011). The marketing channel starting with the pastoralists is for both domestic and export markets.

There are several opportunities for shortcuts along marketing chain. For example, a farmer might sell his/her live animals direct to a dealer, live animal market, or farmer owned cooperative. A farmer may also decide to shorten the marketing chain by selling meat products. At certain times of the year when seasonal demand peaks, even wholesalers and retailers may seek live animals direct from farmers.

\section{Transportation systems}

In Ethiopia, the supply of livestock to the primary, secondary and terminal markets is mostly done through trekking. The findings of Solomon (2004) and Daniel (2008) show that the producers trek their livestock by themselves, relatives, use hired labor and with neighbors. In most cases, a minimum of two drivers are sufficient for cattle trekking but sometimes the number might increase if security is assumed to be problem in the area. In this case, producers may use different means of identification (painting by colors, symbols on skin, etc.) in different parts of the body of livestock to identify their own from others. According to Asfaw et al. (2011), the live animals are either transported in trucks or herded over long distances to feedlot operators, export abattoirs, or major markets. These final market destinations are far away from supply sources, and the transportation costs associated with getting live animals to markets can result in significant weight loss and even death; stock routes are characterized by lack of adequate feed, water, and resting places.

\section{Price determination}

The price of livestock is determined through bargaining at the market. Livestock producers are usually less 
informed about price, supply, and demand situations. Livestock producers are highly fragmented, while there is a concentration of major livestock buyers, a situation which might lead to non-competitive pricing and marketing behavior (Asfaw et al., 2011and Daniel, 2008). Cattle prices increase during rainy season. In this season the number of livestock in the market declines and prices increase. Comparatively increased availability of grass in the range improves the body condition of the animals and enhances the productivity of milk for household consumption, thus in most cases nobody wants to sell cattle during the rainy season. During the dry season, pastoralists forced to sale their cattle at lower prices (Daniel, 2008). The major reasons for the cattle price variation across months/seasons are the change in seasonal feed and water availability. Delay of onset of rainy season results in prolonged dry season and grass fails to grow; livestock are deprived of feed and loose their productivity. Market problems such as trader availability, fluctuation of prices and lack of infrastructure also contribute in cattle price variation. The socioeconomic factors (fasting periods, holidays) and conflict also play a role in livestock price variation.

\section{Types of livestock markets}

The domestic livestock marketing structure in Ethiopia follows four tiers; namely bush, primary, secondary and tertiary/terminal markets. These tiers involve relatively large number of market participants, leading to increased marketing costs and lowering returns to the primary producers, the pastoralists (Belachew, 2004). According to Akililu (2002), Ayele et al. (2003) and Abbey (2004), livestock markets are categorized into primary, secondary, and terminal markets based on types of major market participants, volume of supply per unit of time and the purpose of buying.

\section{Livestock exports}

Asfaw et al. (2011) indicates that Ethiopia exports both live animals and meat to various African countries, as well as the Middle East, where live animals are demanded due to religious and cultural practices. NEPADCAADP (2005) reported that the Middle East and North African countries which are considered important for the country's export in livestock and livestock products are Saudi Arabia, United Arab Emirates, Bahrain, Yemen, Jordan, Kuwait, Oman, Qatar, Iran, Syria and Egypt. Purchasing of live cattle at the markets is performed based on the requirements of the customers. Thus breed, sex, age, weight and sometimes color of the animal for the live export are the major criteria considered by the export abattoirs during purchase (Solomon, 2004).

The export of livestock and livestock products could explain the discrepancy between production and consumption levels, but the actual volume of exports is unknown. This is because the bulk of livestock exports are deemed by the government to be illegal and are, as a consequence, poorly documented. Livestock are exported through formal channels where live animals are directly exported, or in the form of chilled or frozen meat carcass. The other channel of export is the informal and traditional live animal export across borders (Belachew, 2004). The annual outflow of beef cattle from Ethiopia through informal market is very huge. The immediate destinations of this illicit export are Djibouti, Somalia and Kenya which are further re-exported after meeting domestic demands to the Middle East countries (NEPAD-CAADP, 2005). The legal export of both live animal and processed meat is thus constrained due to shortage created by the illicit export. The importance of different export items fluctuates from year to year (IGAD, 2009).

The subsistence production systems in Ethiopia cannot compete with commercial producers in Brazil or Australia. International trade barriers (SPS, tariff and non tariff) impose huge limitations on the country. Export marketing and promotional strategies in destination countries are almost nonexistent. There is no economy of scale to offset costs. In short, the livestock and livestock product marketing systems are not as efficient or as streamlined as those of its competitors (Aklilu, 2008).

Meat Export: LMA (2004) estimated the annual potential for export at 72,000 ton of meat with an equivalent value of USD 136 million. Low levels of export and lack of diversification show the potential growth areas for meat exports in terms of increasing the volume of exports and diversifying into different meat products with more value addition. Export diversification is important to reduce the risk of the meat export market due to demand and price instability. The chilled whole carcass also has a limited shelf-life which requires fast delivery for timely access to the market through channels such as expensive airfreight. To address such problems, it is suggested that vacuum packaging needs to be developed to increase the shelf-life of meat to use cheaper means of transportation (SPS-LMM, 2008).

Live Animal Exports: Ethiopia has been exporting large numbers of animals (about 150,000 per annum) consisting of camels, cattle and shoats to Yemen, Jordan, Egypt and other destinations through Djibouti. The official export figure is insignificant compared to the volume of informal exports that take place through cross border trade to Sudan, Kenya, Somalia and Djibouti. The cross-border trade deprives Ethiopia from accessing export revenues. In any case, the potential to increase live animal exports from Ethiopia is constrained by a number of internal weaknesses varying from poor infrastructure to SPS standards and the recurrent ban imposed 
by the importing countries of the Middle East. Export abattoirs are facing supply shortages (especially of shoats) from time to time. This is understandable, given the current pastoral mode of production where the motive for selling livestock is prompted by immediate cash needs rather than profit, and where the flow of livestock to terminal abattoirs is constrained by the lengthy process of purchasing, collecting and assembling livestock from individuals (Aklilu, 2008).

Hides, skins and leather exports: According to (IGAD, 2009) official exports of hides, skins and leather have been both more stable and more valuable than official livestock and meat exports. For a time in the 1990s, hides, skins and leather were Ethiopia's second largest export earner after coffee. The contribution of the livestock sector (live animals, meat and hides, skins and leather products) to exports has held steady at about $11 \%$ of the national total, with declines in the value of skins, hides and leather being offset by roughly comparable increases in live animal exports. By 2008-09 the position of hides, skins and leather exports had declined to the point where these constituted less than half of the livestock sector's contribution to official exports.

\section{Opportunities and Challenges of Livestock Marketing in Ethiopia Opportunities of Livestock Marketing}

Middle East is one of the major consumers of livestock and livestock products from Ethiopia. The Middle East annually imports 831.66 thousand metric ton of meat; 12.66 million heads of shoats; 159.96 thousand cattle and 29.02 thousand camels. The average annual revenue from these imports by the Middle East amounts to about USD1.94 billion (Belachew and Stuart, 2003). The rapid growth in demand for meat products in the world is a great opportunities for livestock resource-rich countries like Ethiopia to exploit. Recently, there has been a trend of continuous and rapid increases in global consumption, production, and trade of livestock products in developing countries. The factors that led to this increased demand are: population growth, urbanization, rise in income in growing urban centers of developing countries, international influences (globalization and more liberal international trade), and technological changes in the production, communication, and transport sectors (Asfaw et al., 2011).

Ethiopia has comparative advantage in terms of geographic proximity to the Middle Eastern markets, with the potential for the quickest delivery time of fresh meat or meat products. Ethiopia's lowland cattle, sheep, goat, and camel breeds are also highly demanded in the Middle East due to their better taste and the organic nature of their production (Hurissa and Eshetu, 2003). In addition to the growing opportunity to export live animals and meat, there will also be an increase in domestic demand due to urbanization and economic growth.

With growing urbanization, there has been a rapidly developing food service sector (fast food outlets, restaurants, and hotels) in Ethiopia. This will increase the demand for high quality processed dairy products and dairy ingredients. Additionally, the food manufacturing sector, which utilizes dairy ingredients, has been expanding in Ethiopia. There are several bakeries and confectionary factories which require dairy products as their main ingredients; these represent another area of growing market opportunities for dairy producers and dairy product processors and suppliers (Asfaw et al., 2011).

In general, the opportunities of livestock marketing in Ethiopia are resource availability; demand availability both regionally and in the Middle East; proximity to the markets of neighboring countries; development of export-abattoirs within the country and their substantial demand for lowland animals, especially shoats; and the tendency of both the government agencies and the NGOs to work towards integrating the pastoral marketing cooperatives with the export abattoirs supply chains.

\section{Challenges of Livestock Marketing}

Despite the above-mentioned opportunities, livestock producers and other people who engaged in livestock marketing in Ethiopia face various challenges in marketing their livestock and livestock products. According to the finding of Daniel (2008), livestock production constraints include feed shortage; lack of water; animal health related problems such as lesions, weight loss during the dry season, fracture of cattle in the field, mortality, lack of veterinarians etc; problems with socio-economic nature such as many privately fenced areas in the former grazing fields; lack of security or theft; problems such as natural factors (recurrent drought), biological factors (failure of conception, lack of breeding bulls and predators), health factors (impurity of water), feed and water scarcity (cattle are not conditioned timely), labor shortage (herder, water pull, theft, predators) and conflicts.

Feed and water shortage: along export trade routes and at the embankment port availing feed and water in holding grounds are increasingly becoming a serious challenge to the beef cattle export trade. NEPAD-CAADP (2005) indicated that the problem of feed and water is much more pronounced during drought crises, which is a recurrent phenomenon in pastoral ecosystems. Occasionally, seasonal shortage of rainfall, due to its impact on feed availability, forces higher supply to the market. This forced supply is constrained by the inability of the pastoralists to plan sales in accordance with market needs (Belachew \& Jamberu, 2002).

Prevalence of disease: the widely prevalent livestock diseases are major constraints to Ethiopian livestock export (LMA, 2001). Livestock export from Ethiopia is jeopardized by repeated bans, in particular from the 
countries in the Arabian Peninsula, as they are perceived to carrying the risk of introducing a number of transboundary livestock diseases (Wondwosen, 2003). The frequent occurrence of livestock diseases in the country directly inflict a heavy loss on the export abattoirs' business and further regaining of their market takes time which depresses the abattoirs to perform their scheduled activities (LMA, 2004). FAO (1995) stated that the incidence of rinderpest, contagious bovine pleuro-pneumonia, sheep and goat pox, blue tongue, fowl pox, pullorosis, anthrax, blackleg, hemorrhagic septicemia, bovine tuberculosis, brucellosis, etc. have severely limited the livestock production and export potential of the country. Belachew (2004) stated that trade ban by Saudi Arabia and subsequently by Emirates in September 2000 resulted in drastic drops in livestock exports. Over the past few years, the country has lost a substantial market share and foreign exchange earnings because of frequent bans by the Middle East countries due to the Rift Valley Fever and Mad Cow Disease outbreaks, respectively, in the Republic of Yemen and U.K. (Belachew, 2004)

Transportation problem: cattle are transported by road, sea and air for purposes of fattening or slaughter. However, there are no live cattle transport lorries in the country rather they used small trucks from the markets to their holding grounds and used chain trailer to the Djibouti port. The processed meat such as chilled meat export has been taking place using the available cargo space in scheduled passenger flights. The limited spaces by the Airline, forces the abattoirs mostly to operate under capacity. When cargo space is not available, exporters are forced to take back the consignments to their own cold chain facilities. Live cattle export is mainly done by the sea transport through Djibouti, since it is the only port for livestock export from Ethiopia (Daniel, 2008). Proper livestock transport facilities, except those possessed by export abattoirs, do not exist. Thus, trekking animals takes longer time, while transporting them by ordinary trucks is too costly and results in bodily injuries and weight losses (Belachew, 2004).

Inadequate infrastructure: Market infrastructures, such as roads, livestock markets, stock routes, resting places, quarantine stations for assembling and transporting livestock are either poorly developed or virtually absent (Belachew, 2004; Asfaw et al.,2011).

Marketing related problems: The marketing system is not well developed to enhance efficient marketing. Grading and standardization, market information system, promotional activities and planned marketing, which are all attributes of efficient marketing, are not adequately developed to enhance efficiency in the continuous flow of livestock from production areas to terminal markets. Lack of market-oriented production system is another problem in developing organized marketing systems. Pastoralists consider their livestock as a means of savings or capital accumulation. They sell livestock when the need arises for cash income, or when shortage of feed and water occurs. There is no effort to strategically produce for the market by adjusting and planning production to market needs (Belachew, 2004).

\section{CONCLUSIONS}

Ethiopia has the largest livestock population in Africa. This livestock sector has been contributing considerable portion to the economy of the country. It is eminent that livestock products and by-products in the form of meat, milk, cheese, and butter supply etc. provide the needed animal protein that contributes to the improvement of the nutritional status of the people. Livestock also plays an important role in earning foreign exchanges to the country by providing exportable commodities, such as meat, live animals, hides, and skins. On the other hand, draught animals provide power for the cultivation of the smallholdings and for crop threshing virtually all over the country and are also essential modes of transport to take holders and their families long-distances, to convey their agricultural products to the market places and bring back their domestic necessities. Livestock as well confer a certain degree of security in times of crop failure, as they are a "near-cash" capital stock. Moreover, livestock provides farmyard manure that is commonly applied to improve soil fertility and also used as a source of energy such as dung cake as a fuel for fires and as bio-gas energy.

For Ethiopia, opportunities to export livestock and livestock products to Middle Eastern countries and other African countries have been growing. Clearly, Ethiopia has comparative advantage in terms of geographic proximity to the Middle Eastern markets, with the potential for the quickest delivery time of fresh meat or meat products. Ethiopia's lowland cattle, sheep, goat, and camel breeds are also highly demanded in the Middle East due to their better taste and the organic nature of their production

Ethiopia has great potential for increased livestock production and for improved livestock marketing, both for local use and for export. However, expansion was constrained by inadequate feed, prevalence of disease, a lack of support services such as extension services, insufficient data with which to plan improved services, inadequate infrastructure supporting domestic and export markets for live animals, inadequate port facilities, inadequate financial and technical sources for livestock-related businesses, illegal export trade and inadequate information on how to improve animal breeding, marketing, and processing. The high concentration of animals in the highlands, together with the fact that cattle are often kept for status, reduces the economic potential of Ethiopian livestock. The following recommendations are put forward to develop markets and improve the living conditions of the livestock producers. 
* The traditional marketing system, where cattle are sold only when need arises, should be developed into market-oriented production system that takes into account market demands and profits.

* In order to avoid the frequently imposed import bans and increase exports, major diseases should be controlled through the strengthening of the present veterinary services, by increasing access to vaccination.

* Develop major infrastructural facilities for livestock marketing such as livestock routes and transportation facilities, improved slaughter- houses, livestock resting sites, and storage and quarantine facilities at required sites.

\section{REFERENCES}

Abbey A (2004). Red Meat and Poultry Production and Consumption in Ethiopia and Distribution in Addis Ababa. Borlaug-Ruan World Food Prize Intern and national Livestock Research Institute Addis Ababa, Ethiopia.

ACDI/VOCA (Agricultural Cooperative Development International/ Volunteers in Overseas Cooperative Assistance) (2010). End Market Analysis of Ethiopian Livestock and Meat.

Ahmed M M, Bezabih E, Jabbar M A, Tangka F and Ethuni S (2003). Economic and Nutritional Impacts of Market-oriented dairy production in the Ethiopian highlands. Socio-economics and policy Research Working paper 51, ILRI (International Livestock Research Institute), Nairobi, Kenya, 27pp.

Aklilu Y (2002). An Audit of the Livestock Marketing Status in Kenya, Ethiopia and Sudan. Volume I. Community-Based Animal Health and participatory Epidemiology Unit. Pan African Program for the Control of Epizootics, Organization of African Unity/Inter African Bureau for Animal resources.

Aklilu Y (2008). Livestock Marketing in Kenya and Ethiopia: A Review of Policies and Practice. Feinstein International Center, Addis Ababa.

Andargachew K (1990). Sheep Marketing in the Central Highlands of Ethiopia. M.Sc. Thesis Presented to the School of Graduate Studies Alemaya University of Agriculture.

Andargachew K and Brokken R F (1993). Intra-annual sheep price patterns and factors underlying price variations in the central highlands of Ethiopia. Agricultural Economics 8:125-138.

Asfaw N, Shahidur R, and Berhanu G (2011). Livestock Production and Marketing. Development Strategy and Governance Division, International Food Policy Research Institute-Ethiopia Strategy Support Program II, Ethiopia ESSP II Working Paper 26, August 2011.

Ayele S, Assegid W, Jabbar M A, Ahmed M M and Belachew H (2003). Livestock marketing in Ethiopia: A review of structure, performance and development initiatives. Socio-economics and Policy Research Working Paper 52. ILRI (International Livestock Research Institute), Nairobi, Kenya. 35 pp.

Bailey D V, Christopher B B, Peter D L and Francis C (1999). Livestock Markets and Risk Management Among East African Pastoralists.

Barrett C, S Osterloh, P D Little and J G McPeak (2004). Constraints Limiting Marketed Off take Rates Among Pastoralists. Research Brief 04-06-PARIMA. Davis: University of California, Global Livestock Collaborative Research Support Program (GL-CRSP).

Belachew H and Jemberu E (2002). Challenges and opportunities of livestock trade in Ethiopia. Paper presented at the $10^{\text {th }}$ annual conference of Ethiopian Society of Animal Production (ESAP), Addis Ababa, Ethiopia, 22-24 August 2002. ESAP, Addis Ababa, Ethiopia. 33 pp.

Belachew and Stuart (2003). "Livestock Export Zone Study: Technical Requirements and Cost Benefit Analysis (Ethiopia \& Uganda) and Potential Export Markets for Meat and Livestock." Oct. 2003, Nairobi, Kenya.

Belachew H (2004). Livestock Export From Ethiopia: Problems and solutions FAO EXCELEX Project Workshop.

Berhanu K, Fekede F and Kedir N (2003). Gender Based Analysis of Livestock Production Systems at Kuyu wereda in North Shao zone, Ethiopia. Holetta research center, Addis Ababa, Ethiopia. Proceedings of the 14th annual conference of the Ethiopian Society of Animal Production (ESAP) held in Addis Ababa, Ethiopia, September 5-7, 2006.

Central Intelligence Agency (CIA), 2013. The wold factbook.

CSA (Central Statistical Authority) (2007). Agricultural Sample Survey 2006/07. Volume II. Report on Livestock and livestock characteristics. Statistical Bulletin 388. Addis Ababa: FDRE.

CSA (Central Statistical Agency) (2009). Agricultural Sample Survey, 2008/2009 (2001 EC), Report on Livestock and Livestock Characteristics. Statistical Bulletin 446. Addis Ababa: FDRE.

Central Statistical Agency (CSA) (2012). Annual Agricultural Sample Survey.

Daniel T (2008). Beef Cattle Production System and Opportunities for Market Orientation in Borena Zone, Southern Ethiopia. A Thesis Submitted to school of Graduate Studies, Haramaya University.

FAO (1995). Livestock Development Programmes. Country Information Brief Food and Agriculture Organization of the United Nations Ethiopia, Draft June 1995. 
FAO (2004). Livestock Information, Sector Analysis and policy branch. Ethiopia.

Gebremedhin B, Hoekstra D and Samson J (2007). Heading towards commercialization? The case of live animal marketing in Ethiopia. Improving Productivity and Market Success (IPMS) of Ethiopian Farmers Project Working Paper 5. ILRI (International Livestock Research Institute), Nairobi, Kenya. 73 pp.

Girma M (2003). Challenges and Opportunities of Livestock Marketing in Ethiopia. Proc. 10th Annual conference of the Ethiopian Society of Animal Production (ESAP) held in Addis Ababa, Ethiopia, August 22-24, 2002. ESAP, Addis Ababa. 11Pp.

Hurissa B and J Eshetu (2003). In Challenges and opportunities of livestock marketing in Ethiopia, ed. Y. Jobre, and G. Gebru. Proceedings 10th Annual conference of the Ethiopian Society of Animal Production (ESAP), Challenges and Opportunities of Livestock Marketing in Ethiopia, held in Addis Ababa, Ethiopia, August 22-24, 2002. Addis Ababa: ESAP.

Hurissa B (2007). Personal communication.

ILCA (International Livestock Centre for Africa) (1990). Livestock systems research manual. Working Paper 1, Vol. 1. ILCA, Addis Ababa, Ethiopia. 287 pp.

IGAD (Intergovernmental Authority on Development) (2010). IGAD Livestock Policy Initiative. Livestock Exports from Pastoralist Areas: An Analysis of Benefits by Wealth Group and Policy Implications, IGAD LPI Working Paper No. 01-10.

IGAD (Intergovernmental Authority on Development) (2011). IGAD Livestock Policy Initiative. The Contribution of Livestock to the Ethiopian Economy-Part II, IGAD LPI Working Paper No. 02-11.

Kohls R L and J N Uhl (1985). Marketing of Agricultural Products. $6^{\text {th }}$ edition, Macmillan Publishing Company, New York. P624.

Kotler P and Armstong G (2003). Principle of Marketing, 10 ${ }^{\text {th }}$ edition. Hall of India pvt.ltd. New Delhi. Pp5-12.

LMA (Livestock Marketing Authority) (2001). Study on Causes of Cross-Border Illegal Trades in South, Southwest and Eastern Ethiopia, Market Research and Promotion Department, Addis Ababa, Ethiopia.

LMA (Livestock Marketing Authority) (2004). Meat exports market study. MoARD (Ministry of Agriculture and Rural Development), Addis Ababa, Ethiopia.

Mahmud A (2000). Development potential and constraints of hides and skins marketing in Ethiopia. In: R.C. Merkel, G. Abebe and A.L. Goetsch (eds.). The Opportunities and Challenges of Enhancing Goat Production in East Africa. Proceedings of a conference held at Debub University, Awassa, Ethiopia from November 10 to 12, 2000. E (Kika) de la Garza Institute for Goat Research, Langston University, Langston, OK pp. 127-138.

Malcolm B, Jack M and Vic W (2005). The Farming Game. Agricultural Management and Marketing, Second edition. United States of America by Cambridge University Press, New York pp 214-237.

McPeak (2000). Pastoralists' Use of Markets, Cornell University Pastoral Risk Management Project.

Mendoza G (1995). A primer on Marketing Channels and Margins. Lyme Rimer Publishers Inc.,USA.445p.

Misginaw T A (2011). Price Spread Analysis of Cattle in Hadiya Pastoral Areas. Journal of Biology, Agriculture and Healthcare ISSN 2224-3208 (Paper) ISSN 2225-093X (Online) Vol 1, No.1, 2011.

NEPAD-CAADP (New Partnership for Africa's Development-Comprehensive Africa Agriculture Development Program) (2005). Ethiopia: Investment Project Profile "Live Animal and Meat Export"- Preliminary Options Outline. 3pp.

Solomon T (2004). Performance of Cattle Marketing System in Southern Ethiopia with Special Emphasis on Borena Zone. A Thesis Submitted to School of Graduate Studies Alemaya University,Alemaya.

SPS-LMM (2008). Ethiopia Sanitary and Phytosanitary standards and Livestock and Meat Marketing Program (SPS-LMM). Texas Agricultural Experiment Satiation (TAES)/Texas A\&M University System. Addis Ababa, Ethiopia. (Memo).

Stroebel A (2004). Socio-Economic Complexities of Smallholder Resource-Poor Ruminant Livestock Production Systems in Sub-Saharan Africa. Thesis submitted in partial fulfillment for the degree of Doctor of Philosophy. Free State University. Pp 51-69.

Wondwosen A (2003). Influence of Animal Diseases and Sanitary Regulations on Livestock Export Trade and Cases of Export Restrictions. In Challenges and Opportunities of Livestock Marketing in Ethiopia. Proceedings of the 10th annual conference of the Ethiopian Society of Animal Production (ESAP) held in Addis Ababa, Ethiopia, August 21-23, 2003. 